\title{
KETERAMPILAN MERANCANG LEMBAR KERJA SISWA (LKS) BERBASIS LEARNING CYCLE 5E DI MA KHAIRUDDIN GONDANGLEGI
}

\author{
Yuli Ifana Sari ${ }^{1}$, DwiKurniawati ${ }^{2}$, \\ 1,2Program Studi Pendidikan Geografi, Ilmu Pendidikan \\ Universitas Kanjuruhan Malang \\ Jl. S. Supriadi No. 48 Malang \\ Telp (0341) 831532 \\ E-mail: ifana@unikama.ac.id
}

\begin{abstract}
ABSTRAK
LKS merupakan bahan ajar yang digunakan dalam proses pembelajaran. Guru sebagai fasilitator dalam pembelajaran di kelas memiliki peran strategis dalam pengembangan bahan ajar atau LKS.Materi workshop disusun didasarkan atas analisis kebutuhan peserta yang dilaksanakan melalui pelatihan dan pendampingan dengan guru.Rangkaian kegiatanworkshop yaitu: Informasi dan tanya jawab pengembangan LKS berbasis learning cycle materi litosfer.Hasil yang diperoleh dari kegiatan pengabdian antara lain: 1) bahan ajar/LKS dirancang sesuai dengan kebutuhan dan minat peserta didikserta tuntutan kurikulum yang berlaku, 2) guru memiliki keterampilan dalam menggembangkan LKS, 3) guru memiliki komitmen untuk menggembangkan LKS sendiri sebagai alat dalam pembelajaran, dan 4) adanya kesempatan guru dalam meningkatkan profesionalitasnya melalui workshop pengembangan LKS.
\end{abstract}

Kata Kunci: Keterampilan merancang LKS, Workshop

\begin{abstract}
LKS is teaching material used in the learning process. Teachers as facilitator in learning in class has a strategic role to develop teaching materials or worksheets. Material of workshop was prepared based on analysis of the participants needs through training and mentoring with teachers. The step of workshop are: Information and discussion for the development of worksheets based on the learning cycle of lithosphere material. Result of service activities : 1) LKS are design based from necessary, pretension of students and applicable curriculum, 2) teachers have skill to develop LKS, 3) teachers have commitment to develop their own LKS fortheir tool of learning, and 4) teachers have opportunity to improve their professionalism by means of LKS development workshops
\end{abstract}

Keywords: Skill of designing LKS, Workshop

\section{PENDAHULUAN}

Undang-undang Guru dan Dosen Nomor 14 Tahun 2005 pada pasal 8 dinyatakan bahwa kompetensi yang harus dimiliki guru adalah: a. Kompetensi pedagogis, b. Kompetensi kepribadian, c. Kompetensi social dan d. Kompetensi profesional. Berdasarkan empat kompetensi tersebut, maka kompetensi inti yang wajib dimiliki seorang guru adalah: (1) 
mengembangkan kurikulum yang terkait dengan bidang pembelajaran yang diampu, (2) menyelenggarakan kegiatan pembelajaran yang mendidik, (3) mengembangkan materi pembelajaran yang diampu secara kreatif dan (4) memanfaatkan teknologi informasi dan komunikasi untuk berkomunikasi dan mengembangkan diri. Berdasarkan kewajiban tersebut seorang guru harus mampu menyusun bahan ajar yang inovatif dan kreatif sesuai dengan kurikulum, perkembangan kebutuhan peserta didik.

Umumnya guru hanya menyediakan bahan ajar yang monoton, sudah tersedia dan tinggal pakai, serta tidak perlu bersusah payah membuatnya. Dengan kondisi tersebut membuat peserta didik akan merasa bosan mengikuti pembelajaran sehingga pembelajaran menjadi tidak efektif. Faktanya guru kurang mengembangkan kreativitas untuk merencanakan, menyiapkan dan membuat bahan ajar secara matang yang kaya inovasi sehingga menarik bagi siswa. Hal ini tentunya menjadi persoalan dalam pembelajaran di sekolah.Untuk mengatasi permasalahan tersebut salah satunya adalah dengan cara guru atau pendidik perlu membangun dan menumbuhkan kreativitas dari diri sendiri agar mampu membuat dan mengembangkan bahan ajar yang inovatif.

Bahan ajar menurut (Prastowo, 2013) adalah segala bahan (baik informasi, alat maupun teks) yang disusun secara sistematis, yang menampilkan sosok utuh dari kompetensi yang akan dikuasai peserta didik dan digunakan dalam proses pembelajaran dengan tujuan perencanaan dan penelaahan implementasi pembelajaran, misalnya buku pelajaran, modul, handout, LKS, model atau maket, bahan ajar audio, bahan ajar interaktif dan sebagainya.

Salah satu bahan ajar yang digunakan di sekolah adalah Lembar Kerja Siswa (LKS). Lembar Kerja Siswa (LKS) merupakan salah satu bahan ajar cetak berupa lembar-lembar kertas yang berisi materi, ringkasan, dan petunjuk-petunjuk pelaksanaan tugas pembelajaran yang harus dikerjakan oleh siswa sesuai dengan kompetensi dasar yang akan dicapai. Prastowo (2013) menjelaskan bahwa "LKS juga berfungsi sebagai bahan ajar yang mempermudah siswa untuk memahami materi yang ringkas dan kaya akan tugas untuk berlatih serta mempermudah pelaksanaan pembelajaran kepada siswa”.

Fakta di lapangan masih banyak guru menggunakan LKS yang didistribusikan oleh penerbit, tanpa upaya merencanakan, menyiapkan, dan menyusunnya sendiri. Resikonya sangat dimungkinkan jika bahan ajar yang dipakai tidak kontekstual, tidak menarik, monoton dan tidak sesuai dengan kebutuhan peserta didik. Selain itu LKS yang digunakan di sekolah 
masih banyak kekurangan seperti tidak ada petunjuk belajar, kurangnya informasi pendukung, LKS juga tidak mencantumkan tujuan pembelajaran yang harus dicapai oleh siswa, serta gambar yang ada di LKS kurang jelas dan tidak menarik. Menurut (Ditendik, 2008) Pembelajaran yang menarik, efektif, dan efisien tentunya membutuhkan bahan ajar yang inovatif. Untuk itu seorang guru yang profesional harus kreatif agar mampu menyusun bahan ajar yang inovatif, variatif, menarik, kontekstual dan sesuai dengan kebutuhan peserta didik.

Permasalahan mendasar yang terjadi di MA Khairuddin Gondanglegi terkait dengan bahan ajar berupa Lembar Kerja Siswa (LKS) yakni sekolah sama sekali tidak menggunakan LKS dalam pembelajaran khususnya pada mata pelajaran geografi. Padahal keberadaan LKS mempunya fungsi dan manfaat yang besar dalam pembelajaran sehingga dapat membantu guru dan siswa. Menurut Prianto dan Harnoko (1997), fungsi LKS antara lain:

1) Mengaktifkan siswa dalam proses belajar mengajar, 2) Membantu siswa dalam mengembangkan konsep, 3) Melatih siswa untuk menemukan dan mengembangkan proses belajar mengajar, 4) Membantu guru dalam menyusun pelajaran, 5) Sebagai pedoman guru dan siswa dalam melaksanakan proses pembelajaran, 6) Membantu siswa memperoleh catatan tentang materi yang dipelajarai melalui kegiatan belajar, 7) Membantu siswa untuk menambah informasi tentang konsep yang dipelajari melalui kegiatan belajar secara sistematis.

Melalui penggunaan LKS diharapkan siswa dapat termotivasi dalam mempelajari konsep-konsep geografi khususnya pada materi geografi fisik. Materi geogarfi fisik membutukan pemahaman secara kontekstual dalam pembelajarannya. Hal ini dikarenakan banyak konsep konkrit yang dipelajari. Dalam mempelajari geografi fisik maka harus menguasai kumpulan pengetahuan yang berupa fakta, konsep, atau prinsip, membahas tentang fakta serta gejala alam. Fakta dan gejala alam tersebut menjadikan pembelajaran tidak hanya verbal tetapi juga faktual. Oleh karena itu, materi geografifisik perlu diajarkan dengan bantuan learning cycle5Ekarena banyak konsep konkrit yang dipelajari. Pembelajaran berbasis learning cycle5Eakan mengajak siswa mengidentifikasi langsung dengan cara mengeksplorasi dimana siswa dapat melakukan pengamatan, mengumpulkan data, hingga mencapai sebuah kesimpulan.

Fungsi dan manfaat LKS memiliki kesamaan karakteristik dengan model pembelajaran learning cycle $5 E$ yaitu diantaranya siswa dapat aktif dalam pembelajaran, membantu siswa dalam mengembangkan konsep, melatih siswa untuk menemukan dan mengembangkan 
materi yang di pelajari. Learning cycle $5 E$ adalah siklus belajar yang terdiri dari 5 tahapan yaitu engagement, exploration, explanation, elaboration, dan evaluation. Tahap engagement adalah tahap persiapan dan pembangkitan minat siswa. Exploration adalah tahap yang bertujuan untu mengecek pengetahuan siwa. Explanation adalah tahap dimana siswa harus dapat menjelaskan suatu konsep dengan kalimat atau pemikiran sendiri. Tahap elaboration adalah tahap dimana siswa menerapkan konsep dan keterampilan konsep yang telah dipelajari. Tahap evaluation adalah tahap dimana siswa dapat mengeevaluasi diri dengan mengajukan pertanyaan terbuka dan mencari jawaban yang menggunakan oberservasi.

Pembelajaran dengan menggunakan model learning cycle $5 E$ akan membantu siswa dalam membangun pengetahuan yang telah diperoleh melalui aktifitas yang telah dilakukan dalam pembelajaran. Model ini akan memacu siswa untuk berperan aktif dalam pembelajaran sehingga pembelajaran berpusan pada siswa. Khanifatul (2013) menjelaskan bahwa "prinsip student centered menekankan bahwa pembelajaran akan lebih berhasil apabila siswa secara aktif melakukan latihan-latihan secara langsung dan relevan dengan tujuan pembelajaran yang sudah ditetapkan".

Pembelajaran dengan menggunakan model learning cycle $5 E$ pada dasarnya menekankan keaktifan siswa dalam mengikuti pembelajaran. Model ini juga mengutamakan proses dalam pemahaman konsep dan kegiatan pembelajaran yang meliputi kegiatan mengobservasi, merumuskan pertanyaan yang relevan dan membangun konsep baru berdasarkan pengetahuan dan pemahaman yang telah didapat selama pembelajaran. Kegiatan tersebut bertujuan untuk mengembangkan keterampilan ilmiah anak sehingga dengan model learning cycle $5 E$ diharapkan pembelajaran dapat dilakukan secara maksimal dan mendorong siswa menjadi lebih aktif.

Berdasarkan analisis situasi tersebut maka dibuatlah sebuah pengembangan keterampilan merancang Lembar Kerja Siswa (LKS) berbasis learning cycle $5 E$ di MA Khairuddin Gondang legi. LKS berbasis learning cycle $5 E$ tentunya akan berisi lima tahapan/ fase yakni pembangkitan minat (engagement), eksplorasi (exploration), penjelasan (explanation), elaborasi (elaboration), dan evaluasi (evaluation). Hal ini dilakukan dengan cara memberikan pertanyaan tentang prosesfaktual dalam kehidupan sehari-hari yang di sesuaikan dengan materi.

Berdasarkan analisis situasi, beberapa permasalahan yang teridentifikasi di lokasi pengabdian antara lain: 1) pentingnya bahan ajar yang dirancang sesuai dengan kebutuhan 
dan minat peserta didik serta tuntutan kurikulum yang berlaku, 2) dalam pembelajaran guru hanya menggunakan buku paket yang telah disediakan tanpa menggunakan LKS sehingga guru hanya sebagai pengguna hal ini menyebabkan guru minim akan keterampilan mengembangkan LKS, 3) karena dalam pembelajaran hanya menggunakan buku paket saja tanpa menggunakan LKS dapatmenyebabkan konten materi tidak sesuai dengan kebutuhan dan minat siswa, dan 4) terbatasnya kesempatan bagi guru-guru dalam peningkatan pengembangan profesi khususnya dalam hal pengembangan Lembar Kerja Siswa (LKS).

\section{METODE}

Berdasarkan permasalahan yang diuraikan di atas, maka untuk pemecahan masalah dan solusi yang ditawarkan untuk guru geografi di MA Khairuddin Gondanglegi Kabupaten Malang adalah sebagai berikut:

\section{Tabel 1. Kerangka Pemecahan Masalah}

\begin{tabular}{|c|c|c|c|c|}
\hline No & Permasalahan & Metode Pendekatan & $\begin{array}{l}\text { Solusi yang } \\
\text { Ditawarkan } \\
\end{array}$ & Partisipasi Mitra \\
\hline 1 & $\begin{array}{l}\text { LKS yang ada belum menarik dan } \\
\text { sesuai dengan tujuan pembelajaran }\end{array}$ & $\begin{array}{l}\text { Workshop dan } \\
\text { pendampingan }\end{array}$ & $\begin{array}{l}\text { Workshop dan } \\
\text { pendampingan } \\
\text { tentang } \\
\text { pengetahuan } \\
\text { merancang LKS } \\
\text { yang menarik } \\
\text { dan sesuai tujuan } \\
\text { pembelajaran }\end{array}$ & $\begin{array}{l}\text { Menyediakan } \\
\text { tempat untuk } \\
\text { workshop dan } \\
\text { pendampingan }\end{array}$ \\
\hline 2 & $\begin{array}{l}\text { Pemahaman guru dalam membuat } \\
\text { LKS masih perlu ditingkatkan }\end{array}$ & $\begin{array}{l}\text { Workshop dan } \\
\text { pendampingan }\end{array}$ & $\begin{array}{l}\text { Workshop dan } \\
\text { pendampingan } \\
\text { dengan } \\
\text { memberikan } \\
\text { motivasi untuk } \\
\text { meningkatkan } \\
\text { kemampuan guru } \\
\text { dalam membuat } \\
\text { LKS }\end{array}$ & $\begin{array}{l}\text { Menyediakan } \\
\text { bahan ajar, dan } \\
\text { fasilitas wifi untuk } \\
\text { membuat LKS }\end{array}$ \\
\hline 3 & $\begin{array}{l}\text { Pengembangan keterampilan } \\
\text { merancang LKS sangat penting } \\
\text { dalam meningkatkan kualitas } \\
\text { evaluasi pembelajaran }\end{array}$ & $\begin{array}{l}\text { Workshop dan } \\
\text { pendampingan }\end{array}$ & $\begin{array}{l}\text { Workshop dan } \\
\text { pendampingan } \\
\text { guru dalam } \\
\text { meningkatkan } \\
\text { kualitas evaluasi } \\
\text { pembelajaran }\end{array}$ & $\begin{array}{l}\text { Menyediakan } \\
\text { tempat untuk } \\
\text { menyampaikan } \\
\text { sosialisasi }\end{array}$ \\
\hline
\end{tabular}

Khalayak sasaran dalam program pengabdian masyarakat ini adalah guru geografi di MA Khairuddin Gondanglegi Kabupaten Malang. Sedangkan aplikasi pelaksanaannya pengabdi melibatkan 2 mahasiswa yang sudah mengikuti matakuliah evaluasi pembelajaran geografi sebagai pendamping dan motivator di lapangan. 
Tabel 2. Rancangan Evaluasi

\begin{tabular}{|c|c|c|c|}
\hline No & Kriteria & Indikator & $\begin{array}{l}\text { Tolok ukur } \\
\text { keberhasilan }\end{array}$ \\
\hline 1 & $\begin{array}{l}\text { Workshop dan pendampingan } \\
\text { tentang pengetahuan merancang } \\
\text { LKS yang menarik dan sesuai tujuan } \\
\text { pembelajaran }\end{array}$ & $\begin{array}{l}\text { Menjelaskan langkah- } \\
\text { langkah pengembangan } \\
\text { dalam merancang LKS } \\
\text { dan penilaiannya }\end{array}$ & $\begin{array}{l}\text { Guru mampu } \\
\text { merancang LKS yang } \\
\text { menarik dan bermutu } \\
\text { serta memahami } \\
\text { bagaimana cara } \\
\text { penilaiannya }\end{array}$ \\
\hline 2 & $\begin{array}{l}\text { Workshop dan pendampingan } \\
\text { dengan memberikan motivasi untuk } \\
\text { meningkatkan kemampuan guru } \\
\text { dalam membuat LKS }\end{array}$ & $\begin{array}{l}\text { Menjelaskan teori } \\
\text { tentang LKS }\end{array}$ & $\begin{array}{l}\text { Guru mampu } \\
\text { memahami teori } \\
\text { tentang LKS }\end{array}$ \\
\hline 3 & $\begin{array}{l}\text { Workshop dan pendampingan guru } \\
\text { dalam meningkatkan kualitas } \\
\text { evaluasi pembelajaran }\end{array}$ & $\begin{array}{l}\text { Menjelaskan cara } \\
\text { mengevaluasi hasil } \\
\text { pembelajaran geografi }\end{array}$ & $\begin{array}{l}\text { Guru mampu } \\
\text { memahami cara } \\
\text { mengevaluasi hasil } \\
\text { pembelajaran geografi }\end{array}$ \\
\hline
\end{tabular}

Keterampilan mengembangkan LKS dengan menggunakan metode workshop dan pendampingan. Oleh karena para peserta merupakan guru yang sudah memiliki pengalaman dalam melakukan evaluasi, maka penyampaian materi tentang mengembangkan LKS difokuskan untuk merevisi hasil LKS yang sudah ada dan dikembangkan lebih baik lagi. Adapun rangkaian kegiatannya sebagai berikut: 1) Sharing tentang pengembangan LKS yang menarik dan bermutu. Dilanjutkan diskusi untuk merancang LKS materi Litosfer, dan 2) Praktek merancang LKS bersama dengan team pengabdi.

\section{HASIL DAN PEMBAHASAN}

\section{Situasi Pelaksanaan}

Kegiatan dilaksanakan pada hari Kamis, 19 Juli 2018 dan Kamis, 26 Juli 2018 di MA Khairuddin Gondanglegi. Guru yang hadir 7 orang termasuk Kepala Sekolah dan Waka Kurikulum. Pelaksanaan dimulai Pukul 08.00 sampai 12.00 WIB dengan rincian kerja sebagai berikut:

\section{Tabel 3. Situasi Pelaksanaan}

\begin{tabular}{|c|c|c|c|}
\hline Hari/Tanggal & No & Mat e ri & SituasiPelaksanaan \\
\hline \multirow{7}{*}{$\begin{array}{l}\text { Kamis, 19 Juli } \\
2018\end{array}$} & \multirow[t]{4}{*}{1} & Menganalisis langkah- & Peserta antusias mengikuti kegiatan merancang \\
\hline & & langkah pengembangan & LKS meliputi: cara menyusun/ membuat LKS \\
\hline & & $\begin{array}{l}\text { dalam merancang LKS yang } \\
\text { menarik dan penilaiannya }\end{array}$ & $\begin{array}{l}\text { yang baik (Syarat-syarat didaktik, konstruksi, } \\
\text { teknis) dan pengembangan LKS. }\end{array}$ \\
\hline & & & $\begin{array}{l}\text { Terdapat aktivitas diskusi dan Tanya jawab } \\
\text { berkaitan dengan prosedur }\end{array}$ \\
\hline & \multirow[t]{3}{*}{2} & Menyusunan LKS sesuai & Setelah memahami bagaimana cara menyusun \\
\hline & & langkah-langkah & LKS, selanjutnya peserta menyusun \\
\hline & & pengembangan LKS & $\begin{array}{l}\text { pengembangan LKS meliputi: menetapkan SK, } \\
\mathrm{KD} \text {, tujuan dan indicator pembelajaran; } \\
\text { menetapkan prosedur, jenis, dan alat penilaian; }\end{array}$ \\
\hline
\end{tabular}


Kamis, 26 Juli $3 \quad$ Penyusunan LKS berbasis 2018

Learning Cycle $5 E$
4
Penyusunan LKS sesuai dengan pendidikan abad 21 menetapkan dan mengembangkan bahan/ media/ sumber, fasilitas (sarana dan prasarana), dan karakteristik lingkungan siswa.

Kemudian peserta menyusun LKS secara lengkap.

Dalam pelaksanaanya masih terdapat beberapa permasalahan yang dialami peserta yakni menyesuaikan bahan/ media dengan karakteristik siswa.

Peserta menyusun LKS berbasis learning cycle $5 E$ dengan antusias sesuai langkah-langkah yaitu: engagement, exploration, explanation, elaboration dan evaluation. Namun terdapat beberapa peserta yang masih belum memahami bagaimana menyusun LKS berbasis learning cycle $5 E$ dan menyesuaikan dengan materi. Peserta menyusun LKS berbasis abad 21 yang memiliki ciri: berpikir kritis, pemecahan masalah, metakognisi, berkomunikasi, berkolaborasi, inovasi, kreatif, literasi informasi. Diharapkan peserta dapat menyusun LKS sesuai dengan pendidikan abad 21, namun terdapat kesulitan untuk mengaplikasikan semua cirri tersebut sehingga diambil beberapaciri yang bisa digunakan dan disesuaikan dengan pembelajaran geografi.

\section{Faktor Pendukung}

Sebagai faktor pendukung pelaksanaan pengabdian adalah:

1. Adanya dukungan dari Kepala Sekolah untuk mengajak guru-guru mengikuti pengembangan keterampilan merancang lembar kerja siswa (LKS) berbasis learning cycle $5 E$ di MA Khairuddin Gondanglegi.

2. Adanya kepentingan bersama yang saling menguntungkan yakni pihak sekolah dapat menyusunbahan ajar berupa LKS yang dapat digunakan sendiri dalam lingkup sekolah sesuai dengan karakteristik siswa dan dapat meningkatkan kualitas guru dan pembelajaran.

3. Karena membuat bahan ajar sebagai salah satu syarat kenaikan golongan yang disebut sebagai kegiatan pengembangan profesi maka pelatihan ini sangat sesuai dan banyak membantu guru.

4. Fasilitas ruangan yang memadai sehingga proses pelaksanaan penyusunan LKS berjalan dengan lancar.

5. Minat peserta yang tinggi sehingga membuat semangat kami, untuk menyampaikan materi semaksimal mungkin.

6. Banyaknya pertanyaan dari peserta, sehingga menambah hidupnya suasana penyusunan LKS. 


\section{Faktor Penghambat}

Terdapat beberapa faktor penghambat dalam kegiatan ini yaitu:

1. Waktu yang tersedia terbatas dikarenakan harus menyesuaikan dengan jam mengajar para peserta sehingga terdapat beberapa materi yang belum tersampaikan secara tuntas.

2. Sekolah hanya menggunakan LKS cetak dari penerbit sehingga terdapat kesulitan yang dialami guru dikarenakan pertama kali dalam menyusun LKS.

3. Belum ada referensi buku penyusunan LKS sesuai dengan learning cycle $5 E$ dan berbasis $\operatorname{abad} 21$.

\section{Hasil yang Diperoleh}

Hasil yang diperoleh dari kegiatan pengabdian di MA Khairuddin Gondanglegi, sebagai berikut:

1. Terdapat pemanfaatan dalam teknologi pembelajaran, evaluasi akhir belajar, dan pengembangan siswa didalamnya. Hal ini bertujuan untuk mengaktualisasikan berbagai potensi yang dimiliki oleh guru demi pencapaian tujuan pembelajaran.

2. Kemampuan guru dalam menggunakan sumber belajar sangat penting demi menunjang keberhasilan pembelajaran. Salah satunya dengan meningkatkan ketrampilan guru dalam menggunakan LKS pada pembelajaran dikelas dikarenakan kemampuan guru menyusun LKS merupakan kemampuan paedagogik guru.

3. Diperlukan keselarasan antara silabus dan RPP sebagai bahan dasar pengembangan LKS berbasis learning cycle $5 E$ dan sesuai pendidikan abad 21 yang disesuaikan dengan karakteristik siswa.

4. Adanya langkah-langkah dalam learning cycle $5 E$ dalam penyusunan LKS dapat menjadikan sumber pengetahuan baru oleh guru dalam menyusun bahan ajar. Hal ini guna mewujudkan pembelajaran yang menarik, nyaman, menyenangkan dan meningkatkan kemampuan mengajar guru.

5. Dikarenakan pembuatan LKS secara bersamaan dengan pelaksanaan tugas mengajar, maka guru memiliki peran ganda sebagai pengajar/ fasilitator siswa. Hal ini menjadikan semangat bekerja dari para guru, sehingga dapat meningkatkan kemampuan berpikir dan motivasi belajar siswa.

6. Menumbuhkembangkan kebiasaan menulis terutama menyusun bahan ajar berupa LKS demi meningkatkan profesionalisme guru. 
7. Adanya produk hasil penyusunan LKS yang dibuat oleh peserta sehingga menjadi bahan acuan dan rencana ke depan.

Kegiatan pengabdian pengembangan keterampilan merancang lembar kerja siswa (LKS) berbasis learning cycle 5E di MA Khairuddin Gondanglegi untuk meningkatkan profesionalitas guru dapat berjalan dengan lancar. Pengembangan keterampilan merancang LKS memang nyata dibutuhkan khususnya bagi guru geografi di MA Khairuddin Gondanglegi. Mayoritas peserta mengeluh dikarenakan pengetahuan dalam menyusun LKS masih kurang yang artinya kemampuan paedagogik guru perlu ditingkatkan. Guru-guru menyadari sepenuhnya bahwa penyusunan bahan ajar berupa LKS penting sebagai bentuk perwujudan pertanggungjawaban. Guru bertanggungjawab atas kegiatan pembelajaran yang dilaksanakannya sehingga harus menjaga kualitas pembelajarannya. Untuk itu diperlukan penyusunan LKS yang disesuaikan dengan materi dan karakteristik siswa sehingga dapat meningkatkan kualitas pembelajaran dengan menerapkan LKS berbasis learning cycle 5E. Hasil pengembangan LKS akan bermanfaat bagi siswa jika guru menerapkannnya dalam pembelajaran.

Oleh karena itu, guru merasakan banyak manfaat yang diperoleh dari pelatihan ini untuk meningkatkan kemampuannya dalam menulis proposal penelitian tindakan kelas.Guru hendaknya juga bertanggungjawab atas pengembangan ilmunya agar ilmu yangdiembannya dapat dikembangkan dan tidak tertinggal. Selain itu guru seyogyanya melakukan kajiankeilmuan yang menjadi bidangnya agar kajian yang dilakukannya bermanfaat bagi orang banyak atau rekan guru lain.

1. Kurangnya pengalaman penulisan ilmiah (penyusunan proposal).

2. Kurangnya pengalaman guru dalam hal penelitian tindakan kelas.

3. Kurang percaya diri dalam hal mengekspresikan potensi diri dalam bentuk karya ilmiah.

4. Oleh karena itu sangat perlu diupayakan pemecahan permasalahan yang dihadapi para guru tersebut melalui pelatihan Penelitian Tindakan Kelas. Sehingga permasalahan utamanya adalah: 1) Bagaimana meningkatkan kemampuan guru-guru dalam penulisan ilmiah (penyusunan proposal)?, 2) bagaimana meningkatkan kemampuan dan keterampialn guru dalam hal penelitian tindakan kelas?

\section{SIMPULAN}


Berdasarkan hasil dari pelaksanaankegiatan pengembangan keterampilan merancang lembar kerja siswa (LKS) berbasis learning cycle 5E di MA Khairuddin Gondanglegi, maka hasil yang diperoleh adalah sebagai berikut:

1. Pelaksanaan pengabdian pengembangan keterampilan merancang lembar kerja siswa (LKS) berbasis learning cycle 5E di MA Khairuddin Gondanglegi, berlangsung dengan baik dan memuaskan kedua belah pihak.

2. Adanya respon yang positif dari peserta mengingat kegiatan penulisan penelitian tindakan kelas penyusunan LKS merupakan kewajiban guru dalam rangka peningkatan profesionalitasnya.

3. Peserta telah memahami konsep penyusunan LKS dalambentukproduk LKS.

4. Pelaksanaan kegiatan sesuai dengan rencana dan mendapatkan respon yang sangat positif dari peserta.

5. Pelaksanaan dinyatakan berhasil karena target indikator telah tercapai.

6. Peserta termotivasi secara aktif karena nampak adanya antusias untuk memperhatikan dan selalu ingin tahu dengan adanya pertanyaan-pertanyaan yang muncul.

7. Meningkatkan wawasan guru dalam membuat bahan ajar yang disesuaikan dengan materi, model pembelajaran serta karakteristik siswa.

\section{DAFTAR PUSTAKA}

Direktorat Tenaga Kependidikan Direktorat Jenderal Peningkatan Mutu Pendidik danTenaga Kependidikan Departemen Pendidikan Nasional. 2008. Media Pembelajaran dan Sumber Belajar. Materi Diklat Calon Pengawas Sekolah/Pengawas Sekolah. Jakarta.

Khanifatul. 2013. Pembelajaran Inovatif Strategi Mengelola Kelas secara Efektif dan Menyenangkan. Jogjakarta: Ar-Ruzz Media.

Prastowo, Andi. 2013. Panduan Kreatif Membuat Bahan Ajar Inovatif, MenciptakanMetode Pembelajaran yang Menarik dan Menyenangkan, Yogyakarta: Diva Press.

Prianto \& Harnoko. 1997. Perangkat Pembelajaran. Depdikbud. Jakarta. 